\title{
Die relevansievlak(ke) van Galasiërs 3:28 vir die hedendaagse Suid-Afrikaanse samelewing
}

Fika J. van Rensburg

Skool vir Bibliologie \& Bybeltale

PU vir CHO

POTCHEFSTROOM

E-pos: ontjjjvr@puknet.puk.ac.za

\author{
Paul H. Möller \\ Departement Sosiologie \\ PU vir CHO \\ POTCHEFSTROOM \\ E-pos: sosphm@puknet.puk.ac.za
}

\begin{abstract}
The level(s) of relevance of Galatians 3:28 for the present-day South African society

Galations 3:28 has been used by various people. representing different viewpoints, to motwate their positions in terms of a variety of social problems in present-day South African societr: The aim of this article is to determine the levels of relevance of this verse for South African problems, especially those relating to intergroup relations. This is done by giving an exegetical and hermeneutical account of the verse. In this way the article aims to consuruct the meaning which Galatians $3: 28$ w'ould have had for its first readers/hearers, by. Iransporting its present-day readers to its original context, and assisting them to interpret it from that perspective. The article concludes by proposing a concise formulation of God's revelation for the South African context by means of an interpretation of this verse.
\end{abstract}

\section{Inleiding}

Galasiërs 3:28 word uit verskillende oorde as motivering gebruik vir standpunte oor verskeie sosiale probleme en vraagstukke wat in die hedendaagse SuidAfrikaanse samelewing aanwesig is. Die primêre oogmerk met hierdie artikel is om die tersaaklike relevansievlakke van dié teks vir die hedendaagse SuidAfrikaanse samelewing ${ }^{1}$ te bepaal. Die wyse waarop dit gedoen word, is deur 'n eksegetiese en hermeneutiese verantwoording te gee. Só word daar gepoog om die betekenis wat Galasiërs 3:28 vir die eerste lesers/hoorders gehad en hoe hulle dit verstaan het, te konstrueer deur die hedendaagse leser in die eerste lesers/hoorders se gekonstrueerde posisie te verplaas en vanuit sodanige posisie die teks te interpreteer. Op grond hiervan word dan probeer om in 'n neutedop

$1 \quad$ Samelewing verwys na mense wat deur middel van sosiale wisselwerking daagliks met mekaar verkeer. Sosiale wisselverting is die proses waarvolgens mense op in wederkerige wyse teenoor mekaar optree en rcageer. 
'n formulering te gee van dít wat God met dié teks openbaar, en hoe dit op die hedendaagse Suid-Afrikaanse situasie van toepassing gemaak kan word.

\section{Eksegetiese verantwoording}

\subsection{Die tekstuele konteks}

In Galasiërs 3:28 staan die volgende:

\begin{tabular}{|c|c|c|}
\hline UBS (4) & 1933/53-Vertaling & 1983-Vertaling \\
\hline 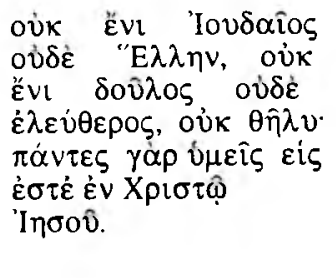 & $\begin{array}{l}\text { Daar is nie meer Jood } \\
\text { of Griek nie, daar is nie } \\
\text { meer slaaf of vryman } \\
\text { nie, daar is nie meer } \\
\text { man en vrou nie; want } \\
\text { julle is almal een in } \\
\text { Christus Jesus. }\end{array}$ & $\begin{array}{l}\text { Dit maak nie saak of } \\
\text { iemand Jood of Griek, } \\
\text { slaaf of vry, man of } \\
\text { vrou is nie: in Christus } \\
\text { Jesus is julle almal een. }\end{array}$ \\
\hline
\end{tabular}

Om die tekstuele konteks van hierdie vers te bepaal, is dit nodig om kortliks na die geheelopset van die brief te kyk.

Redelike eenstemmigheid ${ }^{2}$ bestaan dat dit Paulus se oogmerk met die skrywe van die Galasiër-brief is om die dwaalleer van die Judaïstiese Joods-Christene ${ }^{3}$ te ontbloot en te neutraliseer. In Galasiërs 1:6-7 stel hy sy oogmerk duidelik: "Dit verbaas my dat julle so gou ... afvallig word en 'n ander evangelie aanneem ... Tog is daar mense wat die evangelie van Christus probeer verdraai, en dit is hulle wat vir julle verwarring bring."

Die teksdeel onder bespreking maak deel uit van die liggaamgedeelte van die brief. ${ }^{4}$ Die UBS-teks (4de hersiene uitgawe) beskou Galasiërs 3:21-29 as 'n perikoop, onder die opskrif "Slaves and sons". Die gedeelte Galasiërs 3:26-29

2 Vergelyk byvoorbeeld Coetzee (1976:24). Lategan (1984) gee 'n bruikbare opsomming van verskillende standpunte hieroor.

3 Hierdie dwaalleraars wou kennelik elemente van die Joodse wetsgeregtigheid deel maak van die Christelike geloof. Witherington (1981:594) bespreek dié aspek indringend.

4 Lategan (1984:112) verdeel die brief in drie hoofdele, naamlik "Die evangelie nie na die mens nie" (1:12-2:21), "Die geregtigheid deur die geloof verdedig teenoor besware" (3:1-4:31), en "Die etiese implikasies van die nuwe lewe deur die Gees" (5:1-6:18). Die teksdeel onder bespreking maak volgens hierdie verdeling deel uit van die perikoop 3:22-29 ("Vryheid of gebondenheid") Coetzee (1976:26-29) se verdeling kom in hooftrekke hiermee ooreen. Hy beskou 3:25-4:5 egter as 'n perikoop ("Noudat Christus self gekom het, is dic tyd van dic tugmeester verby"). 
word as 'n subperikoop gedruk.5 Ter wille van die onmiddellike tekstuele verband is dit nodig om die gedagte-opbou van hierdie subperikoop nader te bepaal.

In hierdie hele gedeelte is Paulus besig om aan te toon dat Jood-wees (wat die onderhouding van die wet impliseer) en nie-Jood wees (wat nie-onderhouding van die wet impliseer) nie volgens die evangelie die grondslag vir twee afsonderlike kategorieë mense met betrekking tot die verlossing mag vorm nie. Hy stel in Galasiërs 2:16 dat "'n mens nie van sonde vrygespreek word deur die

wet van Moses te onderhou nie, maar alleen deur in Jesus Christus te glo". In Galasiërs 3:16 word hierdie tema spesifiek aangesny: "Daarom kan ook hulle wat nie Jode is nie, deur Christus Jesus deel kry aan die seën wat God aan Abraham toegesê het".

In Galasiërs 3:15-25 word die argument in 'n sekere sin onderbreek om eers, aan die hand van die testament-beeld, die verhouding tussen die wet en die belofte uiteen te sit. In Galasiërs 3:23-25 word die voorlopige funksie van die wet uiteengesit, 'n funksie wat opgehou het toe die tyd van die geloof aangebreek het. Die geloof bewerkstellig dus 'n verandering: vroeër kon net dié wat die wet onderhou (dus: die Jode) deel kry aan die seën wat God aan Abraham toegesê het (Galasiërs 3:14). Die geloof veroorsaak egter dat ook nieJode deel aan dié seën kry.

Die subperikoop Galasiërs 3:26-28 begin met die relasiemerker yóp (Gal. 3:26) wat aandui dat Galasiërs 3:26-28 die stelling in die voorafgaande motiveer, naamlik dat die geloof ' $n$ verandering ten opsigte van die uitsluiting van nieJode bewerkstellig. Almal (bedoelende Jode én nie-Jode) is kinders van God. Die gedagte-opbou van Galasiërs 3:26 kan skematies soos volg voorgestel word $\mathbf{6}$ :

5 Die 1983 Afrikaanse vertaling volg die UBS na

6 Die teks uit Galasièrs 3:26-28 is telkens in vetdruk gedruk en in 'n blok geplaas, met dirck daarbo ' $n$ interpretasie van die semantiese inhoud van die relasie met die voorafgaande gedagteeenheid. 
Figuur 1: Skematiese voorstelling van die gedagte-opbou: Galasiërs 3:28

3:26-28: Motivering vir die stelling in 3:25 dat die geloof 'n houdingen gedragsverandering bewerkstellig

Die motivering 7 self

\begin{tabular}{|c|c|}
\hline 3::6: & $\begin{array}{l}\text { Almal is immers nou kinders van God deur die geloof in } \\
\text { Christus Jesus }\end{array}$ \\
\hline & Motivering8 vir die stelling dat almal kinders van God is \\
\hline$\longrightarrow$ & \begin{tabular}{|l}
$3: 27:$ Immers, julle wat in Christus gedoop is, het julle \\
met Christus beklee
\end{tabular} \\
\hline & Implikasie ${ }^{9}$ van die stelling dat almal kinders van God is \\
\hline$\longrightarrow$ & $\begin{array}{l}\text { 3:28: Dit maak (dus) nie saak of iemand Jood of Griek, } \\
\text { slaaf of vry, man of vrou is nie: in Christus Jesus is } \\
\text { julle almal een }\end{array}$ \\
\hline
\end{tabular}

Implikasie ${ }^{10}$ van die hele argument (eintlik vanaf $2: 15$ )

3:29: Dus, aangesien julle aan Christus Jesus behoort, is julle ook nakomelinge van Abraham en erfgename kragtens die belofte van God

Die relasiemerker $\gamma$ óp aan die begin van 3:26 merk die rede-komponent in 'n gevolg-rederelasie. Die rede is: Julle is almal kinders van God. Die gevolg is: Ook nie-Jode kry deel can die seen wat God aan Abraham toegesê her (3:14).

8 Die relasiemerker yap aan die begin van 3:27 merk die rede-komponent in 'n gevolg-rederelasie. Die rede/grond is: Julle het julle met Christus beklee. Die gevolg is: Julle is almal kinders van God.

9 Die relasie tussen 3:28 en die voorafgaande is asindeties gemerk. Hierdie asindeton word as die merker van die gevolg-komponent in 'n rede-gevolg-relasie geinterpreteer. Die gevolg is: Dit maak nie meer saak of iemand Jood of Griek (ens.) is nie. Die rede is: Almal is nou kinders van God (3:26).

10 Die relasie tussen 3:29 en die voorafgaande word met $\delta \dot{\varepsilon} \ldots$ a $\alpha \alpha$ gemerk as die gevolgkomponent in ' $n$ rede-gevolg-relasie. Die gevolg is: Ook julle is nakomelinge van Abraham en erfgename kragtens die belofte van God. Die rede is: Die hele voorafgaande gedeelte waarin die hele saak oor Jode en nie-Jode (en wetsonderhouding en nie-wetsonderhouding) bespreek is. 
Die tekstuele konteks van Galasiërs $3: 28$ is duidelik. Paulus kom hier in sy argument tot die gevolgtrekking dat ook nie-Jode deel in die seën wat God aan Abraham toegesê het.11 Dit gaan nie oor die opheffing van die onderskeid tussen Jode en Grieke nie, maar om hulle gelykheid voor God.

Paulus noem egter ook twee verdere kategorieë wat nie in die voorafgaande argument gefigureer het nie. Hy verwys na 'n stratifikasiesisteem ${ }^{12}$ wat op die sosiale klassifikasie van mense in sosiaal-ongelyke statusposisies berus: dié van slaaf/vrymens en man/vrou. Wat die sosiaal-ongelyke statusposisie van man/vrou betref, word bykomend ook dié van geslagsongelykheid in terme van toegeskrewe (aangebore) status beklemtoon.13 Op grond van die tekstuele konteks kan dit op geen wyse anders geïnterpreteer word as die onderskeid Jood/Griek nie, naamlik: hy stel die norm dat geloof in Christus nie hierdie sosiale kategorieë ophef nie, want dit is funksioneel en etnosentries ${ }^{14}$ omdat dit $^{2}$ kultureel vasgestel en in ' $n$ patriargale ideologie ingebed is. Persone is egter ondanks hulle sosiaal-ongelyke verwerfde (slaaf/vrymens) en toegeskrewe $(\mathrm{man} / \mathrm{vrou})$ statusposisies voor God gelyk.

\subsection{Intertekstuele konteks}

\subsubsection{Elders in die Nuwe Testament}

Paulus gebruik die teëstelling Jood-Griek ook in sommige van sy ander briewe binne min of meer dieselfde konteks. Voorbeelde hiervan is die volgende:

- In Christus Jesus is dit nie van belang of jy besny is of nie. Al wat van belang is, is geloof wat deur liefde tot dade oorgaan (Gal. 5:6).

- ... niemand wat in Hom glo, sal teleurgestel word nie. Niemand nie! Dit maak dus geen verskil of ' $n$ mens ' $n$ Jood of ' $n$ Griek is nie ... want een wat die Naan van die Here aanroep, sal gered word (Rom. 10:1113).

11 Witherington (1981:596) beskou ook Galasiërs 3:26-29 as 'n samevatting van wat tot dusver gesê is.

12 Strarifikasiesisteem dui op bogeskiktheid en ondergeskiktheid en word op tocgeskrewe kentrckke soos velkleur (ras), geslag en afkoms gebaseer - kentrekke wat in persoon se prestige, voorregte, invloed, mag, beroep en sosiale verhoudings bepaal

13 Dit is nie moontlik om bloot in die lig van die tekstuele konteks te bepaal warom Paulus skielik hierdie twee par-begrippe in sy gevolgtrekking toevoeg nie. Op intertekstuele en buitetekstuele gronde is daar egter wel aanduidings. Vergelyk die bespreking hieronder.

14 Etnosentrisme verwys na die neiging on te aanvaar dat jou kultuur of leefwyse bogeskik aan dié van ander is (Schaefer \& Lamm, 1995:604). 
- Hier is dit nie van belang of iemand Griek of Jood is nie, besny of nie besny nie, anderstalig, onbeskaaf, slaaf of vry nie. Hier is Christus alles en in almal (Kol. 3:11).

In twee Skrifgedeeltes word die teenstelling gemaak tussen Jood en nie-Jood:

- Ek skaam my nie oor die evangelie nie, want dit is 'n krag van God tot redding van elkeen wat glo, in die eerste plek die Jood, maar ook die nie-Jood (Rom. 1:16).

- Ewige heerlikheid, eer en vrede skenk Hy aan elkeen wat goed doen, in die eerste plek aan die Jood, maar ook aan die nie-Jood (Rom. 2:10).

Daar is ook Bybelgedeeltes wat die veelheid van funksies, ten spyte van die eenheid, beklemtoon: Romeine 12:4-6, 1 Korintiërs 12:4-30 en Efesiërs 4:1113.

\subsubsection{Buite-Bybelse tekste}

Madeleine Boucher (1969) toon aan dat Paulus dalk Galasiërs 3:28 geskryf het as 'n bewuste reaksie op die Joodse formuliergebed waarin 'n man God gedank het dat $\mathrm{Hy}$ hom nie as heiden, slaaf of vrou gebore laat word het nie. ${ }^{15}$ 'n Tweede moontlikheid wat sy noem, is dat dit 'n vry aanhaling is van 'n ander uitspraak:

If a poor man says anything, one pays little regard; but if a rich man speaks, immediately he is heard and listened to. Before God, however, all are equal: women, slaves, poor and rich. ${ }^{16}$

Boucher oortuig nie met haar tweede argument nie, want Paulus het etlike perikope bestee om aan te toon dat Jood en nie-Jood gelyk is voor God. In sy gevolgtrekking voeg hy nou twee sosiale statusonderskeidings in wat hy weet by sy lesers leef, en hy pas die argument wat hy ten opsigte van die onderskeiding Jood en nie-Jood gebruik het, ook op slaaf/vryman en vrou/man toe.

15 Vergelyk Boucher (1969:53) vir verskeie primêre bronne ter stawing. Sy noem ook ander navorsers wat haar standpunt deel.

16 Uit die Genesis Rabbah, in 'n kommentaar op Psalm 55(56):3 (vgl. Boucher, 1969:53-54). Die laatdatering van hierdie aanhaling maak dit onseker of dit in die eerste eeu reeds bekend was. Boucher (1969:55-58), alhoewel sy erken dat die datering 'n probleem skep, gebruik die parallel op ' $n$ interessante wyse om aan te toon dat daar ten tye van die skryf van Galasièrs reeds ' $n$ erkenning was van die feit dat vroue (en slawe) voor God gelyk is met mans (en base). Sy argumenteer dan dat Paulus hierby aansluit. Soos by die Jode, sê sy, wil Paulus egter ook nie hể dat vroue se sosiale rol en funksie in die gemeente gelykgestel word aan diê van die man nie. 
Dit blyk dus dat Paulus sensitief is vir die situasie waarin hy hom bevind, vir die verskille en ooreenkomste tussen die sosiale, kulturele en strukturele leefwêrelde van daardie tyd. Hierdie leefwêreld het minstens uit die volgende sosiale en nie-sosiale objekte bestaan:

\section{Figuur 2: Sosiaal-kulturele en strukturele leefwêrelde}

\begin{tabular}{|c|c|}
\hline Sosiale objekte & Nie-sosiale objekte \\
\hline \multirow[t]{2}{*}{$\begin{array}{l}\text { Persone en sosiale } \\
\text { groeperings: } \\
\text { - Jood/Griek } \\
\text { - vrymens/slaaf } \\
\text { - man/vrou }\end{array}$} & $\begin{array}{l}\text { Kultuurverskeidenheid wat gebaseer is op: } \\
\text { - Waardes (oortuigings oor wat wenslik, } \\
\text { reg, fatsoenlik was) } \\
\text { - Norme (voorskrifte, bv. wette of gedrags- } \\
\text { reëls, waaraan gekonformeer of waarvan } \\
\text { afgewyk kon word) } \\
\text { - Ideologieë (regverdiging van 'n lewens- } \\
\text { en wêreldbeskouing wat deur ander } \\
\text { aanvaar moes word) } \\
\text { Simboliese betekenis wat aan die } \\
\text { kategorieë Jood/Griek, vrymens/slaaf, } \\
\text { man/vrou geheg is }\end{array}$ \\
\hline & $\begin{array}{l}\text { Struktuurverskeidenheid wat gebaseer is } \\
\text { op: } \\
\text { - Rolle (man/vrou, vrymens/slaaf, } \\
\text { Jood/Griek) } \\
\text { - Verwerfde statusposisie (vrymens/slaaf) } \\
\text { - Toegeskrewe statusposisic (man/vrou, } \\
\text { Jood/Griek) }\end{array}$ \\
\hline
\end{tabular}

Geloof in Christus hef nie verskille tussen sosiale objekte (Jood/Griek, vrymens/slaaf, man/vrou), tussen verskillende kulture (leefwyses) of tussen strukture op nie. Desondanks die verskille is alle mense wat in Jesus Christus glo, in status voor God gelyk. Geloof in Jesus integreer mense ondanks bogenoemde verskille.

\subsection{Buite-tekstuele konteks}

Daar is gedeë navorsing oor die interpersoonlike verhoudings tussen Jode en Grieke, slawe en vrymense asook vrou en man in die tipiese eerste-eeuse samelewings, vanuit sowel sosio-historiese as sosio-wetenskaplike hoeke 
gedoen. ${ }^{17}$ Voordat 'n oorsig van die tersaaklike data hieroor gegee word, word eers 'n sosiologies-teoretiese verantwoording oor die onderhawige problematieke gegee.

\subsubsection{Sosiologies-teoretiese verantwoording}

Die funksionele integrasie van die Jode van daardie tyd, naamlik om groepseenheid te bevorder, was op intraverhoudings gefokus. Hiervoor het sosiale waarde-oriëntasies en persoonlike motiveringsoriëntasies (vgl. Parsons \& Shils, 1951:80-84) gegeld wat 'n stratifikasiesisteem, 'n samehorigheidsgevoel, stereotipes 18 en etnosentrisme oor verskille tussen Jood/Griek, vrymens/slaaf en man/vrou in stand gehou het, soos in Figuur 3 aangetoon word:

\section{Figuur 3: Sosiale waarde- en persoonlike motiverings- oriëntasies}

\begin{tabular}{|l|l|}
\hline Oriëntasies & Tipes \\
\hline Sosiale waardes & $\begin{array}{l}\bullet \text { Spesifiekheid } \\
\bullet \text { Kwaliteit }\end{array}$ \\
\hline Persoonlike motivering & $\begin{array}{l}\text { Affektiwiteit } \\
- \text { Diffuusheid }\end{array}$ \\
\hline
\end{tabular}

Die sosiale waarde-oriëntasie, spesifiekheid (vgl. Parsons \& Shils, 1951:82), dui op die subjektiewe beoordeling van die teëstelling Jood/Griek, slaaf/vrymens en $\mathrm{man} / \mathrm{vrou}$ op grond van norme (voorskrifte, wette) wat spesifiek op dié sosiale tiperings toepasbaar en vir hulle betekenisvol is. Paulus se idee is dan hiervolgens dat geloof in Christus spesifiek is en dat mense daardeur in 'n geloofseenheid geïntegreer word, ongeag kultuur-, rasse- (Jood/Griek), en geslagsverskille (man/vrou), of sosiale statusposisies (slaaf/vrymens).

Die sosiale waarde-oriëntasie, kwaliteit (vgl. Parsons, 1952:64), verwys na die subjektiewe beoordeling van die teëstelling Jood/Griek, slaaf/vrymens en man/ vrou op grond van die status wat deur geboorte aan 'n persoon of groep ten aansien van onder meer kultuur- en rasseverband asook geslag toegeskryf is. Dit word dus nie deur middel van prestasie verwerf nie. Op grond van dié toegeskrewe status aan primordiale groepe (groepe waarvan lidmaatskap nie

17 Van die belangrike studies hieroor is Balch (1981), Stambaugh en Balch (1986) en Meeks (1983).

18 Stereotipes word aangeleer en dui op 'n onakkurate asook oorvereenvoudigde veralgemening van 'n kategorie mense (Theodorson \& Theodorson, 1990:602. 
opgesê kan word nie) gee die Jode voorkeur aan en ken 'n bogeskikte (verhewe) posisie toe aan die Jood, die vrymens en die man.

In terme van hierdie model kan Paulus se argument soos volg geinterpreteer word: verlossing hang nie af van 'n bogeskikte en ondergeskikte, verwerfde of toegeskrewe statusposisie en/of van die lidmaatskap van primordiale groepe (Jood, vrymens, man) nie. Slegs die geloof in Jesus Christus is hiervoor deurslaggewend. Geloof in Christus skakel bogeskiktheid en ondergeskiktheid op grond van enige verskille uit en stel nie slegs elke persoon en groep voor God gelyk nie, maar bewerkstellig ook 'n eenheid wat alle mensgemaakte grense, onderskeidings asook klassifikasies oorbrug.

Die persoonlike motiveringsoriëntasie, affektiwiteit (vgl. Parsons et al. 1953:66, Parsons \& Shils, 1951:80), tree na vore wanneer 'n persoon of groep se gesindheid en houding in verhoudings met en die beoordeling van Jood/Griek, slaaf/ vrymens, man/vrou op grond van emosies (subjektiewe ingesteldheid) ter sprake kom. Verlossing deur geloof in Jesus Christus moet veroorsaak dat die gelowige se emosionele (subjektiewe) evaluerings en ervarings van en teenoor die naaste ook omvorm word.

Die persoonlike motiveringsoriëntasie, diffuusheid (vgl. Parsons, 1952:66; Parsons \& Shils, 1951:83), hou ook verband met persepsies (subjektiewe beoordeling) oor ander. Diffuusheid beklemtoon die feit dat die onderskeie sosiale groeperings van Jood/Griek, vrymens/slaaf en man/vrou 'n algemene betrokkenheid teenoor mekaar ten opsigte van verskeie aangeleenthede behoort te hê. Funksioneel-spesifieke verhoudings sluit 'n algemene betrokkenheid van mekaar uit omdat dit bloot op die statusposisie en rol van 'n persoon of sosiale groepering fokus. Paulus beklemtoon dat die gelowige, in navolging van Christus, 'n persoon in sy totale menswees moet beskou.

Vervolgens word 'n oorsig van die tersaaklike data oor die verhoudings tussen Jode en Grieke, slawe en vrymense, en vrou en man in die tipiese eerste-eeuse samelewings gegee.

\subsubsection{Die verhouding vrou-man}

\subsubsection{Die rolverwagting ten opsigte van vroue}

Vroue uit die hoër klasse was volgens die Griekse en Romeinse tradisie verplig tot 'n nederige en onopvallende lewenswyse (Stambaugh \& Balch, 1986:111). Die nuwer godsdienste het vroue egter groter vryhede en meer statusgelykheid met mans as die tradisionele staatsgodsdienste toegelaat (Meeks, 1983:25; Stambaugh \& Balch, 1986:123-124). Hierdie verskynsel is deur teëstanders beleef as 'n bedreiging van die orde van die huishouding en van die welsyn van 
die samelewing (Balch, 1981:65-80). Vreemde godsdienste is dus dikwels om hierdie rede as 'n sosiale en politieke bedreiging beskou.

Plutarchos (1956:310) skryf byvoorbeeld in sy brief aan Pollianos en Euridikê waarin hy riglyne oor die huwelik gee, die volgende:

Dit hoort daarom so dat 'n vrou slegs dié gode in wie haar man glo, moet dien en ken; en dat sy die voordeur dig sluit vir alle vreemde rituele en uitlandse bygelowe. Immers, vir geeneen van die gode is dit verdienstelik dat ' $n$ vrou skelm en geheime rites uitvoer nie.'19

\subsubsection{Gedragsvoorskrifte vir die verhouding man-vrou in die huwelik}

Die patriargale gedragsvoorskrif dat die vrou in die huwelik aan haar man onderdanig moet wees, is tipies nie net van die Christendom en Judaïsme nie. Balch (1981:23-31, 33-59) toon aan hoedat daar ten minste sedert die tyd van Plato (ongeveer 380 v.C.), en juis in die tyd wat Galasiërs geskryf is, verskeie dokumente ${ }^{20}$ is van opdragte aan die vrou om aan haar man onderdanig te wees. Die hele idee dat daar in hierdie patriargaalgerigte verhouding (soos ook by die staat en die verhouding tussen 'n eienaar en sy slaaf) noodwendig 'n gesagsdraer en 'n gesagsonderdaan moet wees, word dus in die destydse samelewing as aksiomaties, dus as vanselfsprekend aanvaar (Balch, 1981:61).

\subsubsection{Die verhouding slaaf-vrymens}

Balch (1981:23-31, 33-59) verwys na oorvloedige getuienis dat daar gedragsvoorskrifte vir die verhouding tussen eienaars en slawe is, waarin - soos in die nuwe Testament - van die slawe onderdanigheid geëis word. Een van die baie belangrike onderdele van sulke onderwerping was dat die slaaf inval by die godsdienstige praktyke van die huishouding waarvan hy deel is (Balch, 1981:74; Verner, 1983:3). Die slawe is dus as deel van die huishouding beskou, en het ook 'n aandeel aan die godsdienstige gebruike gehad. Romeine het aanstoot geneem as hulle slawe tot die Judaïsme of Christendom bekeerd geraak het en gevolglik nie meer aan die tradisionele rites wou deelneem nie (Stambaugh \& Balch, 1986:124).

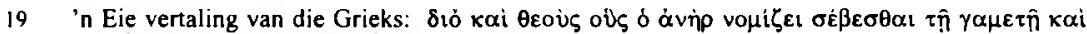

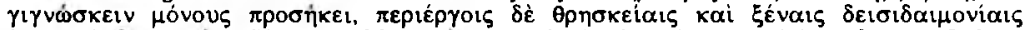

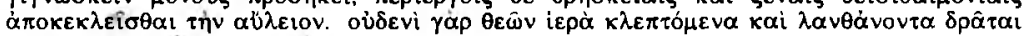

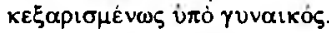

20 Batch (1981:23-62) toon met aanhalings en beredenering aan dat die tersaaklike klassieke topoi wat by Plato en Aristoteles voorgekom het, bekend was by en bespreek is deur die MiddelPlatoniste, die Peripatetici, die Stoïsyne, die Epikuriërs, die Hellenistiese Jode en die NeoPithagoreers. 


\subsubsection{Die verhouding Jood-Griek}

Balch $(1981: 67,73)$ toon aan dat die Judaïsme in die volksoog dieselfde etiket as die Isis- en Dionusos-kultus gedra het, en gevolglik dieselfde tipe kritiek op die lyf geloop het, naamlik dat hulle die gesagsverhoudings in die huishouding, by name dié tussen man en vrou, versteur het. Die verdedigende reaksie was juis om onder andere aan te toon dat die Joodse wet absolute onderwerping van die vrou aan die man eis. ' $n$ Voorbeeld hiervan is by Josefos, in paragraaf 201 van sy Oor die vroeë geskiedenis van die Jode, Deel 2 (Josefos, 1956:372):

Die vrou, sê die Wet, is met betrekking tot alles ondergeskik aan die man. Daarom moet sy gehoorsaam wees, nie om haar te verneder nie, maar sodat sy leiding kan kry. God het immers aan die man die gesag gegee. 21

Die volgende aanhaling uit Tacitus (1902:128), in die vyfde boek van sy Historiarum laat blyk watter sosiale probleme die Romeinse owerheid met Jode en Proseliete (persone wat pas tot die Jodendom bekeer is) ervaar het:

Immers, hulle (die Jode) hou vol om belasting en bydraes daarheen (Jerusalem) te stuur, terwyl hulle op uiters laakbare wyse die voorvaderlike godsdienste minag. ... maar teenoor al die ander tree hulle met vyandigheid en haat op. ... Dié wat tot hulle gebruike bekeer raak, doen dieselfde dinge (haat ander volke, is onsedelik, laat hulle besny) en die vroegste onderrig wat hulle ontvang, is om die gode te verag, hulle vaderland te verraai, en nie meer agting te hê vir hulle ouers, kinders en broers nie.22

Philo (1950b:53) skryf in Boek 4 van sy Oor die verordeninge in besonderhede dat nuwe bekeerlinge tot die Judaïsme deur hulle bekering veroorsaak dat hulle vroeëre land- en volksgenote nou hulle "dodelike vyande" word. Proseliete het vreemdelinge geword in hulle ou sosiale milieu. ${ }^{23}$

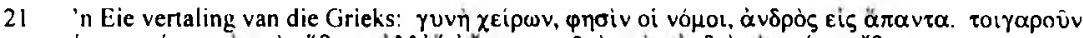

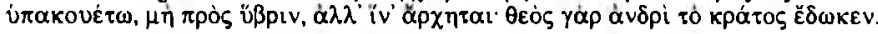

22 'n Eie vertaling van die Latyn: Nam pessimus quisque spretis religionibus patriis tributa et stipes illuc congerehant. ... sed adversus omnes alios hostile odium. ... transgressi in morem eorum idem usurpant, nec quicquam prius inbuuntur quam contemnere deos. exuere patriam. parentes liberos fratres vilia habere.

23 Die volgende gedeeltes uit Philo bevestig hierdie verwerping uit die samelewing na bekering tot die Joodse geloof: paragraaf 273 van sy tweede bock Oor drome (1958:564); paragraaf 51 en 317 van sy ecrste boek onr Die verordeninge in besonderhede (1950a:126-128, 282-282); paragraaf 17-26 van sy Die verhuising van Abraham (1949:140-146). 


\section{Gevolgtrekking}

\subsection{Buite-tekstuele konteks}

Die buite-tekstuele konteks gee onteenseglike getuienis daarvan dat daar in die tipiese eerste-eeuse samelewings gefikseerde beskouings was oor die sosiale rol wat vroue en slawe (en hulle teenpole: mans en vrymense) moes speel. ${ }^{24}$ Dit is ook duidelik dat daar groot vooroordele tussen Jode en nie-Jode bestaan het. Hierdie vooroordele (houdings) het in intergroepverhoudings by wyse van etnosentrisme en diskriminasie neerslag gevind.

Dit is dus hoogs waarskynlik dat Paulus se gevolgtrekking in Galasiërs 3:28 'n verrassende nuwe element vir sy eerste lesers/hoorders bevat het. Dié nuwe element behels onder andere die gelykheid van die onderskeie partye voor God. Baie navorsers meen dat Paulus se uitspraak ook impliseer dat Christen-vroue en Christen-slawe se sosiale statusposisies moes verander vanaf dié van ondergeskikte tot dié van gelyke. Sodanige afleiding kan egter nie op grond van Galasiërs 3:28 in sy verskillende kontekste gemaak word nie.

In Galasiërs 3:28 kom Paulus tot die gevolgtrekking dat ook nie-Jode deel het aan die seën wat God aan Abraham toegesê het. Dit gaan nie oor die opheffing van die sosiaal-kulturele onderskeid tussen Jode en Grieke nie, maar om hulle gelykheid voor God. In die lig van al die vooroordele wat daar tussen Jode en nie-Jode was, is dit 'n belangrike eksplisiete implikasie wat Paulus stel.

Alles dui daarop dat Paulus met die noem van die twee verdere kategorieë (slaaf/vrymens en vrou/man) geen nuwe argument aanvoor nie. Hy brei doodeenvoudig dit wat hy so pas oor die onderskeid Jood/Griek beredeneer het, ook ten opsigte van die statusposisie-onderskeiding slaaf/vrymens en vrou/man uit. Dus, hy stel nie dat geloof in Christus hierdie verwerfde en toegeskrewe statusposisiekategorieë ophef nie, maar dat persone ondanks hulle statusposisies of geslag, voor God gelyk is (vgl. Coetzee, 1965:191-193; Strack \& Billerbeck, 1926:557-563). Tewens, die voorbeeld wat Jesus stel, is om, ten spyte van verwerfde en toegeskrewe statusposisies, mekaar nie te beheer en te manipuleer nie, maar om mekaar, ongeag fisiese, kulturele en strukturele verskille, uit liefde te dien (vgl. Herron, 1980:539). Juis in die voorbeeld wat Jesus stel, word die hiërargiese mag- en gesagsmodel van bogeskikte en ondergeskikte oorheersing na 'n horisontale dienverhouding verander. In hierdie dienverhouding geld die

24 Balch $(1981: 67,73)$ se stelling dat Judaisme in die volksoog dieselfde etiket as die Isis- en Dionusos-kultus gedra het as gevolg van hulle standpunt oor die gesagsverhoudings in die huishouding. by name dié tussen man en vrou, verdien verdere ondersoek. Sodanige ondersoek kan aantoon dat Boucher (1969) se hipotese nie so vergesog is nie. 
Fika J. van Rensburg \& Paul H. Moller

waardes nederigheid, onderdanigheid en onopvallendheid vir alle groepe en kategorieë mense.

\subsection{Hermeneutiese verantwoording}

Met 'n hermeneutiese benadering word 'n dialoog tussen vraag en antwoord, tussen wetenskaplike en situasie gevoer (Coetzee, 1989:16-17). Die vraag is kort en saaklik: Hoe is dit wat God in Galasiërs 3:28 openbaar op die hedendaagse Suid-Afrikaanse samelewing van toepassing? Of anders gestel: Hoe is dit wat God in Galasiërs 3:28 openbaar, op die daaglikse sosiale wisselwerking tussen mense in Suid-Afrika van toepassing?

'n Kort vraag lei dikwels tot 'n lang antwoord. Hier is die antwoord amper so kort soos die vraag.

\subsubsection{Negatiewe verantwoording}

Galasiërs 3:28 sê niks oor die sosiale rolle (spesifieke gedragspatrone wat met sosiale statusposisies geassosieer word) of die sosiale wisselwerking (die proses waarvolgens mense daagliks op 'n wederkerige wyse teenoor mekaar handel en reageer) wat tussen man/vrou, Jood/Griek, en slaaf/vrymens bestaan het nie. Die sosiale rolle, gepaardgaande statusposisies en wisselwerkingspatrone (samewerking wat in onderdanigheid neerslag vind) word as gegewe aanvaar omdat dit funksioneel was en 'n houding van bogeskiktheid en eksklusiwiteit weerspieël het. Daarop word nie kritiek gelewer nie, en die bestaande rolle, statusposisies en wisselwerkingspatrone word ook nie spesifiek gepropageer nie.

Dit is gevolglik nie geldig om met 'n beroep op Galasiërs 3:28 bepaalde aanpassings ten opsigte van die sosiale rol- en statusposisie van byvoorbeeld die vrou, of die bestendiging van die status quo met betrekking tot wisselwerkingspatrone (byvoorbeeld samewerking) te bepleit nie. Ander Skrifdele moet dus vir hierdie tipe vraagstelling ontgin word. 25

\subsubsection{Positiewe verantwoording}

Galasiërs 3:28 sê egter wel baie oor godsdienstige chauvinisme wat op die hedendaagse Suid-Afrikaanse samelewing toegepas kan word. Dit is duidelik dat biologiese afstamming wat 'n bepaalde status aan 'n persoon of groep loeskryf (Jood/Griek, man/vrou) geen grond is vir 'n bevoorregte posisie voor God nie. Dieselfde geld vir sosiale rolle en die sosiale statusposisie wat in 'n

25 Hierdie standpunt kom in hreë trekke ooreen met dié van House (1988:47-56) en Litfin (1979:258-271). 
spesifieke samelewing daarmee gepaard gaan (Jood/nie-Jood, man/vrou, vrymens/slaaf): dit is geen grond en dien geen funksie vir 'n bevoorregte, eksklusiewe posisie voor God nie. 'n Samelewing funksioneer soos 'n liggaam: elke persoon en groep vervul 'n unieke funksie wat, met die gawe(s) wat van die Heilige Gees ontvang word, tot die heil van die geheel 'n bydrae lewer. Só beskou, kan geen persoon, etniese of rassegroep sigself hoër as ander ag nie, want godsdienstige chauvinisme dra geen gewig met betrekking tot die waarde van 'n persoon of groep in die oë van God nie (vgl. Carlson, 1980:131).

Gelowiges in Suid-Afrika wat hulle dus aan enige vorm van godsdienstige chauvinisme skuldig maak, word tot inkeer geroep deur die argument soos dit saamtrek in Galasiërs 3:28. Die gevolge wat godsdienstige chauvinisme vir die hedendaagse Suid-Afrikaanse samelewing inhou, is die volgende: by diegene wat as gevolg van eksklusiwiteit de jure (deur middel van wette) en de facto (deur middel van tradisies en gewoontes) uitgesluit word, ontstaan 'n gevoel van vervreemding. ${ }^{26}$ Dit vind neerslag in 'n belewing van magloosheid, betekenisloosheid, normloosheid ${ }^{27}$, isolasie en selfvervreemding 28 (vgl. Seeman, 1959: 784-790). Insgelyks is godsdienstige chauvinisme manifesdisfunksioneel ${ }^{29}$, want dit destabiliseer en ontwrig intragroep- en intergroepverhoudings. Destabilisasie en ontwrigting is konflikgenererend wat vooroordeel ${ }^{30}$ en diskriminasie ${ }^{31}$ aanwakker. Christen-wees in die hedendaagse Suid-Afrikaanse samelewing moet daarom ook blyk uit die daaglikse wisselwerking tussen mense wat bogenoemde vervreemdingsbelewenisse asook destabilisasie en ontwrigting teëwerk. Soos die eerste Christene moet hedendaagse Christen-Suid-Afrikaners nie in die eerste plek poog om sosiale, kulturele en strukturele verskille te negeer nie. Hulle houdings en gedrag

26 Vervreemding dui in dié konteks op die vernietiging van betekenisvolle verhoudings tussen verskillende mense en groepe as gevolg van godsdienstige chauvinisme.

27 Normloosheid impliseer die belewenis dat bestaande waardes en norme nie meer ' $n$ invloed op gedrag uitoefen nie omdat godsdienstige chauvinisme sommige mense en groepe uitsluit. As gevolg van uitsluiting bestaan onduidelikheid en onsekerheid oor watter gedragsvoorskrifte gevolg moet word.

28 Selfvervreemding verwys na die gevoel dat 'n persoon nie uitdrukking aan sy/haar vermoëns, potensiaal of persoonlikheid kan gee nie as gevolg van die uitsluiting wat godsdienstige chauvinisme meebring (vgl. Wallace \& Wallace, 1989:413).

29 Manifes-disfunksioneel dui op die destabiliserende en bedoelde ontwrigting wat godsdienstige chavvinisme in die versteuring van intragroep-en intergroepverhoudings veroorsaak.

30 Vooroordeel verwys na 'n negatiewe en vyandige houding teenoor 'n persoon of groep.

31 Diskriminasie dui op handelinge wat op 'n persoon of groep gerig word ten einde diesulkes van hulle regte en voorregte te ontneem. 
Fika J. van Rensburg \& Paul H. Moller

tydens daaglikse wisselwerking teenoor ook die minderes in die eie en ander kultuur moet egter totaal verskillend wees van dié van nie-Christene. Christus se voorbeeld moet dus nageleef word!

\section{Bronnelys}

ALAND, B., Aland, K., Karavidopoulos, J, Martini. C.M., Metzger, B.M. eds. 1993. The Greek New Testament. 4th revised edition. Stuttgart : Deutsche Bibelgesellschaft.

BALCH, D.L. 1981. Let wives be submissive: The domestic code in 1 Peter. Chicago : Scholars Press. (Society of Biblical Literature Monograph Series 26.)

BOUCHER. M. 1969. Some unexplored parallels to 1 Cor. 11:11-12 and Galatians 3:28: The New Testament on the role of women. (atholic Biblical Quarterly, 31:50-58.

CARLSON, D.E. 1980. Can sociology be Christian? (In De Santo, C.P., Redekop, C. \& Smith-Hinds. W.L., eds. A reader in sociology: Christian perspectives. Scottdale : Herald. p. 125-134.)

COETZEE, J.C. 1965. Volk en Godsvolk in die Nuwe Testament. Potchefstroom : Pro Rege Pers.

COETZEE, J.C. 1976. Die blye boodskap. 'n Gids deur die boeke van die Nuwe Testament. 1. Die briewe van Paulus. Potchefstroom : Pro Rege.

COETZEE, J.K. 1989. The quest for a more human society - a different sociology? Grahamstown : Rhodes University.

HERRON, R.W. 1980. What makes a family Christian? (In De Santo, C.P.. Redekop, C. \& Smith-Hinds, W.L., eds. A reader in Sociology: Christian perspectives. Scottdale : Herald. p. 533-544.)

HOUSE, W.W. 1988. Neither .. male nor female ... in Christ Jesus. Bibliotheca Sacra 145 47-56.

JOSEFOS. 1956. ПREPI APEAIOTHTOL IOY $\triangle A I \Omega N^{\circ} \Lambda$ OTOE $\triangle E Y T E P O \Sigma$. (Oor die vroeë geskiedenis van die Jode, Deel 2). (In Thackeray, H. St. J. Josephus. London : Willian* Heinemann.)

LATEGAN, B.C. 1984. Galasiërs. (In Du Toit, A.B., red. Handleiding by die Nuwe Testament, Band V: Pauliniese Briewe: Inleiding en teologie. Pretoria : NG Kerkboekhandel.)

LITFIN, A.D. 1979. Evangelical feminism: Why traditionalists reject it. Bibliotheca Sacra, 136:258-271.

MEEKS, W.A. 1983. The first urban Christians. The social world of the apostle Paul. New Haven : Yale University Press.

PARSONS, T'. 1952. The social system. London: Tavistock.

PARSONS, T. \& SHILS, E.A. 1951. Toward a general theory of action. Cambridge : Harvard University Press.

PARSONS. T., BALES, R.F. \& SHILS, E.A. 1953. Working papers in the theory of action. New York : Free Press. 
PHILO. 1949. חIEPI AחOIKIAE. (Oor die verhuising van Abraham). (In Colson, F.H. \& Whitaker, G.H. Philo. London : Heinemann. Vol. IV: 121-266.)

PHILO. 1950a. MEPI TSN EN MEPEI $\triangle I A T A \Gamma M A T \Omega N$. (Oor die verordeninge in besonderhede). (In Colson, F.H. Philo. London : Heinemann. Vol. VII:97-607.)

PHILO. 1950b. IIEPI TSN EN MEPEI $\triangle$ IATACMATSN. (Oor die verordeninge in besonderhede). (In Colson, F.H. Philo. London : Heinemann. Vol. VIII:6-56.)

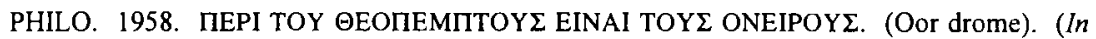
Colson, F.H. Philo. London : Heinemann. Vol. V:433-579.)

PLUTARCHOS. 1956. ГAMIKA ПAPAГГE 1 MATA. (Advies aan bruid en bruidegom). (In Babbitt, F.C. Plutarch's Moralia. London : Heinemann. Vol. II:298-343.)

SCHAEFER, R.T. \& LAMM, R.P. 1995. Sociology. New York : McGraw-Hill.

SEEMAN, M. 1959. On the meaning of alienation. American Sociological Review, 24(1): $783,791$.

STAMBAUGH, J.E. \& BALCH, D.L. 1986. The New Testament in its social environment. Philadelphia : Westminster.

STRACK, H.L. \& BILLERBECK, P. 1926. Die Briefe des neuen Testaments und die Offenbarung Johannis erläutert aus Talmud und Midrasch. München : Beck'sche Verlagsbuchhandlung.

TACITUS, C. 1902. Historiarum, Liber V. (In Godley, A.D. The Histories of Tacitus, Books III, IV, and V. With introduction and notes. London : MacMillan. Book V:125-142.)

THEODORSON, G. \& THEODORSON, L. 1990. Sociology: principles and applications. New York: West.

VERNER, D.C. 1983. The household of God. The social world of the Pastoral Epistles. (SBL Dissertation Series 71.) Chico, California : Scholars Press.

WALLACE, R.C. \& WALLACE, W.D. 1989. Sociology. Boston : Allyn \& Bacon.

WITHERINGTON, B. 1981. Rite and rights for women-Galatians 3:28. New Testament Studies, 27:593-604. 